\title{
Spatiotemporal changes in forest loss and its linkage to burned areas in China
}

\author{
Zhiwei Wu ${ }^{1,2,3} \cdot$ Saijia Yan $^{1} \cdot$ Lei He $^{1} \cdot$ Yanlong Shan $^{4}$
}

Received: 23 May 2019 / Accepted: 19 July 2019 / Published online: 1 November 2019

(C) The Author(s) 2019

\begin{abstract}
Fire-induced forest loss has substantially increased worldwide over the last decade. In China, the connection between forest loss and frequent fires on a national scale remains largely unexplored. In this study, we used a data set for a time-series of forest loss from the Global Forest Watch and for a MODIS-derived burned area for 20032015 to ascertain variations in forest loss and to explore its relationship with forest fires (represented by burned areas) at the country- and forest-zone levels. We quantified trends in forest loss during 2003-2015 using linear regression analysis and assessed the relation between forest
\end{abstract}

Project Funding: This research was funded by the National Science Foundation of China under Grant Numbers 31570462 and 41701514 and the Scientific and Technological Research Project of the Jiangxi Provincial Department of Education under Grant Number GJJ160275.

The online version is available at http://www.springerlink.com.

Corresponding editor: Yanbo Hu.

Zhiwei Wu

wuzhiwei@jxnu.edu.cn

Yanlong Shan

shanyl@163.com

1 Key Laboratory of Poyang Lake Wetland and Watershed Research, Ministry of Education, Jiangxi Normal University, Nanchang 330022, People's Republic of China

2 School of Geography and Environment, Jiangxi Normal University, Nanchang 330022, People's Republic of China

3 Jiangxi Provincial Key Laboratory of Poyang Lake Comprehensive Management and Resource Development, Jiangxi Normal University, Nanchang 330022, People's Republic of China

4 Forestry College, Beihua University, Jilin 132013, People's Republic of China loss and burned areas using Spearman's correlation. Forest loss increased significantly $\left(264.8 \mathrm{~km}^{2} \mathrm{a}^{-1} ; R^{2}=0.54\right.$, $p<0.01)$ throughout China, with an average annual increase of $11.4 \%$ during 2003-2015. However, the forest loss trend had extensive spatial heterogeneity. Forest loss increased mainly in the subtropical evergreen broadleaf forest zone $\left(315.0 \mathrm{~km}^{2} \mathrm{a}^{-1} ; R^{2}=0.69, p<0.01\right)$ and tropical rainforest zone ( $\left.38.8 \mathrm{~km}^{2} \mathrm{a}^{-1} ; R^{2}=0.66, p<0.01\right)$, but the loss of forest decreased in the cold temperate deciduous coniferous forest zone $\left(-70.8 \mathrm{~km}^{2}\right.$ year $\left.^{-1} ; R^{2}=0.75, p<0.01\right)$ and the temperate deciduous mixed broadleaf and coniferous forest zone $\left(-14.4 \mathrm{~km}^{2} \mathrm{a}^{-1} ; R^{2}=0.45, p<0.05\right)$. We found that $1.0 \%$ of China's area had a significant positive correlation $(r \geq 0.55$, $p<0.05$ ) with burned areas and $0.3 \%$ had a significant negative correlation $(r \leq-0.55, p<0.05)$. In particular, forest loss had a significant positive relationship with the burned area in the cold temperate deciduous coniferous forest zone ( $16.9 \%$ of the lands) and the subtropical evergreen broadleaf forest zone (7.8\%). These results provide a basis for future predictions of fire-induced forest loss in China.

Keywords Forest loss - Forest fire - Burned area · Spatiotemporal variability $\cdot$ Correlation analysis

\section{Introduction}

Forests play a vital role in the maintenance of the Earth's ecological balance and mitigation of climate change (Bonan 2008), but forest loss is widespread in various countries (Hansen et al. 2013; Da Ponte et al. 2017; Harris et al. 2017). Studies based on ground observations and satellite data have shown that global forest loss has been remarkably high over the last decade (Hansen et al. 2013; Heino et al. 2015; Keenan et al. 2015). For example, global forest loss 
was 0.19 million $\mathrm{km}^{2} \mathrm{a}^{-1}$ during 2000-2012 (Hansen et al. 2013). Forest loss has a significant impact on ecological processes and functions of forest ecosystems (e.g., biodiversity loss and ecosystem service reduction) (Foley et al. 2007; Betts et al. 2017) and environments (e.g., greenhouse gases emission) (van der Werf et al. 2009; Chiriaco et al. 2013). Thus, there is a need to elucidate the spatiotemporal patterns, trends, and drivers of forest loss (Molin et al. 2017; Curtis et al. 2018) because such loss is an important component of global changes (Trumbore et al. 2015).

Fire has long been considered a major driver of spatiotemporal changes in forest loss (Curtis et al. 2018; Reilly et al. 2018). For example, about $67 \times 10^{6}$ ha of forests burned annually worldwide during 2003-2012 (van Lierop et al. 2015). Moreover, studies have suggested that fire frequency and the area burned could substantially increase with the prolonged growing seasons predicted with warming climates (Liu et al. 2010; Wotton et al. 2010; Abatzoglou and Williams 2016). Such altered fire regimes will likely increase forest loss because the effects of fires will be amplified in warmer, drier climates (Stephens et al. 2013; Brando et al. 2014). Thus, in this study, we focused on the role of fire in shaping spatiotemporal patterns of forest loss, which may help to elucidate the vulnerability of forests to fire and their resilience after a fire event (Tepley et al. 2017).

Forest fires occur frequently in China (Adams and Shen 2015; Chen et al. 2017). For example, about $78.6 \%$ of the land in China was affected by fire during 2001-2016 (Chen et al. 2017). Fires have caused substantial loss of forests in China. For example, on 6 May 1987, a fire in the boreal forests of northeastern China burned $\sim 1.3 \times 10^{6}$ ha and significantly affected forest resources and the environment (Xiao et al. 1988; Cahoon et al. 1994). Although the patterns and drivers (e.g., urban expansion) of forest loss have been examined in some regions of China (Jia et al. 2015; Zhai et al. 2017; Zhou et al. 2017), an understanding of the effects of fires on forest loss on a national scale for China is still lacking. Filling this gap in our knowledge will increase the accuracy of predictions of future trends in forest change (loss or gain) in China.

China's climate ranges from tropical to arctic and from rainy to extremely dry, and forest ecosystems range from subtropical to boreal forests (Piao et al. 2004), resulting in diverse fire regimes (Chen et al. 2017). For example, smaller fires occur most frequently in the hot, humid subtropical evergreen broadleaf forests of southern China. In contrast, fires in the cold temperate deciduous coniferous forests of northeastern China usually account for the majority of the burned area in the country (Tian et al. 2013; Chang et al. 2015). Studies have shown that forest loss to fires may be positive, negative, or unrelated, depending largely on the vegetation conditions and fire regimes considered (Perry et al. 2012; Reilly et al. 2018). Consequently, evaluating forest loss and fire relationships at different spatial scales is essential. Accordingly, we conducted our study at two spatial scales: (1) all of China and (2) six forest zones throughout China.

National-level forest and fire inventory data have not been freely available to the public or are often incomplete (Lehtomaki et al. 2015; Fornacca et al. 2017), especially for remote and less-populated areas. In contrast, global observations using sensors on space-borne satellites have provided multiple regional or global thematic forest and fire data sets (e.g., the Global Forest Change products and MODIS fire products) (Giglio et al. 2010; Hansen et al. 2013), which are usually freely available to the public. Consequently, satellite imagery data have been widely used to monitor forests and fire dynamics at large spatial and temporal scales (Sannier et al. 2016), especially in areas where spatial and temporal forest and fire inventory data are lacking or not publicly available (Fornacca et al. 2017), as is the case for China.

In this study, we combined multi-sensor satellite observations to estimate trends in forest loss and its linkage to fire (herein represented by the burned area) during 2003-2015 across China and in six forest zones, including a group of vegetation zones not dominated by forests, in China. Specifically, the aims of this study were to (1) investigate spatiotemporal patterns of forest loss in China, (2) analyze relationships between forest loss and burned area, and (3) assess variations in the forest loss-burned area relationships among forest zones.

\section{Materials and methods}

\section{Forest zones and fire regimes in China}

China has five forest zones: (I) cold temperate deciduous coniferous forest zone (low fire frequency but high average burned area); (II) temperate deciduous mixed broadleaf and coniferous forest zone; (III) warm temperate deciduous broadleaf-mixed forest zone (low forest coverage and low forest fire frequency); (IV) subtropical evergreen broadleaf forest zone (high coverage and fire frequency, but low average burned area); and (V) tropical rainforest zone (high forest coverage, but low fire frequency). There are three other vegetation zones in China that are not typically dominated by forests: temperate grasslands (low fire frequency, but high average burned area), temperate steppes and desert region, and Qinghai-Xizang plateau alpine region (very low forest coverage and rare fires) (Guo et al. 2017). Because these three vegetation zones have also experienced forest loss 
Fig. 1 Spatial distribution of forest zones and types in China. Zones: I, cold temperate deciduous coniferous forest zone; II, temperate deciduous mixed broadleaf and coniferous forest zone; III, warm temperate deciduous broadleaf-mixed forest zone; IV, subtropical evergreen broadleaf forest zone; $\mathrm{V}$, tropical rainforest zone; VI, vegetation zones in China that are not typically dominated by forests

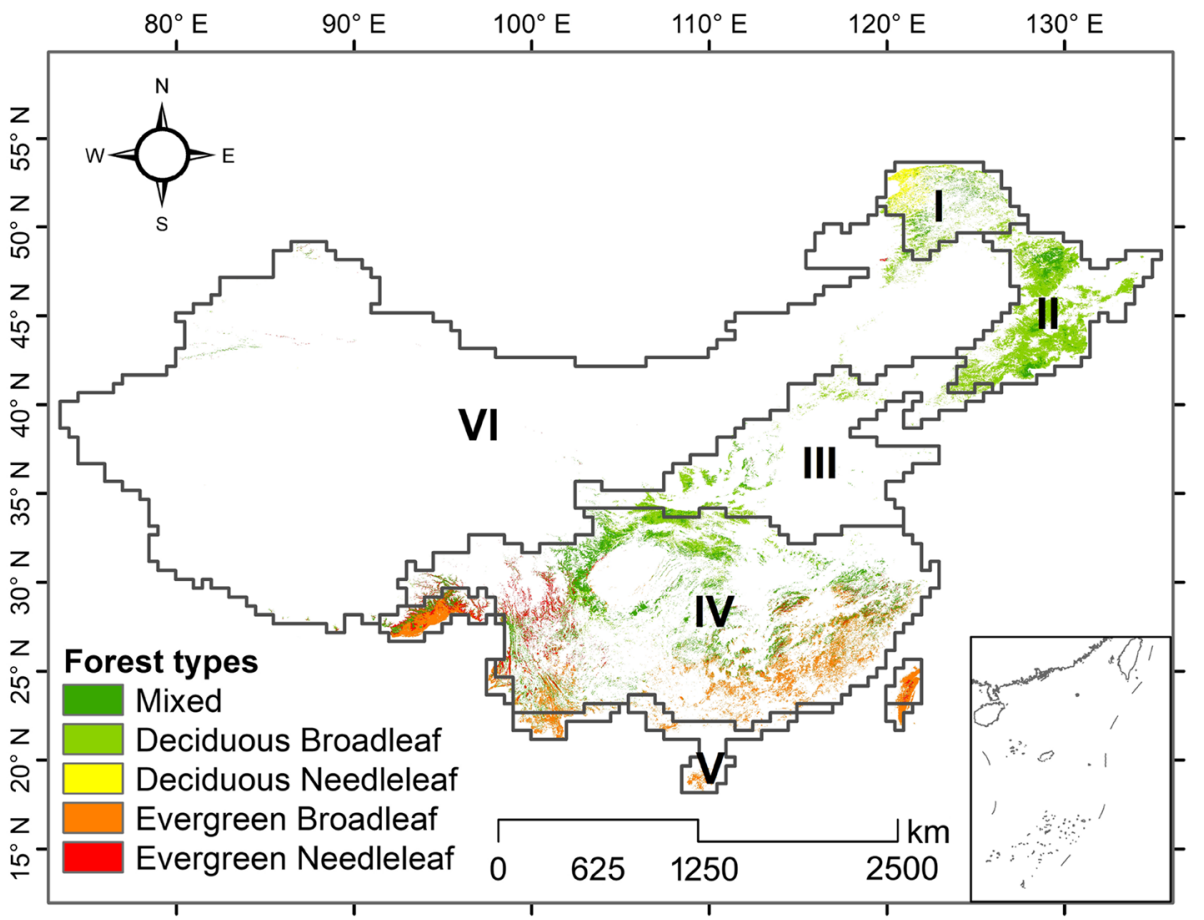

during our study period (2003-2015), we included them in our data analyses. Consequently, we derived six forest zones. The forest-zone data were obtained using a digitized 1:1,000,000-scale vegetation map of China (Fig. 1).

\section{Overall study approaches}

We obtained Landsat-based forest loss data for 2003-2015 from the Global Forest Watch project (https://glad.umd. edu/). We obtained data on the total burned area from the Global Fire Atlas (2003-2015) from NASA's Carbon Monitoring System Program (https://www.globalfiredata. org/). We divided China into grid cells with a $0.5^{\circ} \times 0.5^{\circ}$ spatial resolution. We then calculated forest loss and the burned area for each year (2003-2015) and grid cell. Linear regression using the ordinary least squares approach was used to identify temporal trends of forest loss and burned area over the study period for each $0.5^{\circ} \times 0.5^{\circ}$ grid cells. We conducted Spearman's correlation analysis to investigate the relationships between forest loss and burned area. To account for scale effects on variation in patterns and trends of forest loss, we analyzed the burned area-forest loss relationship at two scales: all of China and six forest zones. All data processing and statistical analyses were conducted using the R software version 3.5 (R Core Team 2018).

\section{Data sources}

\section{Forest loss data}

We obtained a global forest loss data set from the Global Land Analysis and Discovery Laboratory in the Department of Geographical Sciences at the University of Maryland (https://glad.umd.edu/) for January 2003 to December 2015. The forest loss data set was generated by Hansen et al. (2013) using multispectral satellite images from the Landsat 5 thematic mapper (TM), the Landsat 7 thematic mapper plus (ETM+), and the Landsat 8 Operational Land Imager (OLI) sensors. These Landsat satelite imagies were obtained from the U.S. Geological Services Earth Resources Observation and Science archive. The pre-processing of Landsat images included (1) image resampling, (2) converting digital values (DN) to top of atmosphere (TOA) reflectances, (3) cloud/shadow/water screening and quality assessment, and (4) image normalization. For each band, three categories of spectral metrics were calculated during vegetation growing season: (1) minimum ( $\min )$, maximum (max) and percentiles $(10,25,50,75$ and $90 \%$ percentiles) of reflectance values; (2) mean reflectance values between percentiles (max-10\%, 10-25\%, 25-50\%, 50-75\%, 75-90\%, 90\%-max, min-max, 10-90\%, 25-75\%); (3) linear regression slope of 
band reflectance value and image data. The training data set was derived from image interpretation methods, including mapping crown and no-crown categories using very high spatial resolution data (such as Quickbird images), existing percentage tree cover layers from Landsat data (Hansen et al. 2011), and global MODIS percentage tree cover layers (Hansen et al. 2003). The relationship between the training data set (percentage tree cover) and the Landsat spectral metrics was established through a bagged decision tree methodology. Based on this relationship, the map of global tree cover for a given year was generated by the decision tree methodology with a spatial resolution of $30 \mathrm{~m}$. Details on the forest loss data set were described by Hansen et al. (2013).

In the forest loss data set, forests (trees) was defined with a 30-m pixel scale as areas with the presence of vegetation taller than $5 \mathrm{~m}$ and tree canopy cover greater than $20 \%$. Forest loss was defined as a stand replacement (e.g., the conversion from natural forest to other land uses) disturbance or the $100 \%$ removal of tree cover canopy (e.g., $>50 \%$ tree cover changed to a $0 \%$ tree cover) for a given year (Hansen et al. 2013). Spatially, pixels (spatial resolution of $30 \mathrm{~m}$ ) were encoded as either 0 (no loss) or a value in the range of specific years (e.g., 2003-2015), representing forest loss detected primariliy in the given year, respectively. The forest loss data had been validated by FAO statistics, LiDAR detection, and other satellite measurements, and were shown to have an overall accuracy higher than $99 \%$ (Hansen et al. 2013). To be congruent with the spatial resolution of burned area data, the forest loss data were aggregated in grid cells of $500 \times 500 \mathrm{~m}$ spatial resolution.

China releases national forest resource inventory report every 5 years. We compared the areas of forest loss between the Landsat-based data set in this study and China's national forest resources inventory data set during two 5-year periods, i.e., 2004-2008 and 2009-2013. The amount of forest loss between these two data sets is close. Specifically, according to China's seventh (2004-2008) and eighth (2009-2013) forest resources inventory data set, approximately $37,700 \mathrm{~km}^{2}$ and $34,307 \mathrm{~km}^{2}$ of forest were converted to non-forest, respectively. In the Landsat-based data set, national forest loss for 2004-2008 and 2009-2013 were 30,096 km² and $33,072 \mathrm{~km}^{2}$ respectively.

\section{Burned area data}

We obtained a Global Fire Atlas (2003-2015) from NASA's Carbon Monitoring System Program (https://www.globa lifedata.org/). This fire atlas contains the ignition location (latitude and longitude coordinates), perimeter, and other information regarding individual fires based on the MODIS
Collection 6 MCD64A1 burned area product (spatial resolution of $500 \mathrm{~m}$ ) (Andela et al. 2019). The fires were projected in the World Geodetic System 1984 (WGS84, EPSG: 4326). We converted the fire shape files into raster-format fire data with a pixel size of $0.0045099747^{\circ}$ (spatial resolution of $500 \mathrm{~m}$ ) in the ArcGIS environment. The MODIS Land Cover Type product (MCD12Q1), covering 2003-2015 with a spatial resolution of $500 \mathrm{~m}$, was used to identify forest land cover.

The area of each pixel of the fires was calculated using the following equation ( $\mathrm{Li}$ et al. 2015):

Area $=R^{2} \cdot \operatorname{res} \cdot k \cdot\left\{\sin \left[k\left(\right.\right.\right.$ lat $\left.\left.+\frac{\text { res }}{2}\right)\right]-\sin \left[k\left(\right.\right.$ lat $\left.\left.\left.-\frac{\text { res }}{2}\right)\right]\right\}$,

where $k=\frac{\pi}{180}, R=6371.004 \mathrm{~km}$, and res $=0.0045099747^{\circ}$. Area represents the area of the pixel; $R$ is the radius of the Earth; res is the resolution of the pixel; $k$ is the conversion factor from degrees to radians; lat is the latitude of the center of the pixel.

\section{Statistical analysis}

We divided China into grid cells with $0.5^{\circ} \times 0.5^{\circ}$ spatial resolution (total 4103 grid cells). For each grid cell, we calculated forest loss and burned area for the year. Using the $0.5^{\circ} \times 0.5^{\circ}$ grid cells as statistical units, we quantified the relationship between forest loss and burned area at two scales: all of China and six forest zones. All statistical analyses were conducted using R software version 3.5 (R Core Team 2018).

\section{Linear regression analysis}

Linear regression using the ordinary least-squares approach was used to identify trends in the temporal change in forest loss over the study period for each $0.5^{\circ} \times 0.5^{\circ}$ grid cell. The trend in temporal change was calculated as the slope of linear regressions against the year of the study period (2003-2015), as follows:

Slope $=\frac{n \sum_{i=1}^{n}\left(i X_{i}\right)-\left(\sum_{i=1}^{n} i\right)\left(\sum_{i=1}^{n} X_{i}\right)}{n \sum_{i=1}^{n} i^{2}-\left(\sum_{i=1}^{n} i\right)^{2}}$

where slope indicates the trend in forest loss; $i$ is the year from 2003 to $2015 ; n$ denotes the number of years; and $X_{\mathrm{i}}$ is the forest loss during year $i$. A positive slope indicates an increase in forest loss during the period. A $t$ test was used to detect the significance level of the trend ( $p<0.05$ was considered significant). 


\section{Correlation analysis}

In each $0.5^{\circ} \times 0.5^{\circ}$ grid cell, we tested for a correlation between forest loss and burned area between 2003 and 2015 using Spearman's correlation coefficient $(r)$, calculated as follows:

$r_{x y}=\frac{\sum_{i=1}^{n}\left[\left(x_{i}-\bar{x}\right)\left(y_{i}-\bar{y}\right)\right]}{\sqrt{\sum_{i=1}^{n}\left(x_{i}-\bar{x}\right)^{2} \sum_{i=1}^{n}\left(y_{i}-\bar{y}\right)^{2}}}$,

where $r_{x y}$ is the correlation coefficient between forest loss and burned area; and $\bar{x}$ and $\bar{y}$ are the means of the two variables. $r_{\mathrm{xy}}$ values range from -1.0 to 1.0 , with higher negative/positive values indicating a stronger correlation. A $t$-test was used to determine the significance level of the correlations $(p<0.05$ was considered significant).

\section{Results}

\section{Spatiotemporal changes in forest loss}

On average, China lost $6209.2 \mathrm{~km}^{2}$ of forests during 2003-2015. As shown in Fig. 2, forest loss increased significantly $\left(264.8 \mathrm{~km}^{2} \mathrm{a}^{-1} ; R^{2}=0.53 ; p<0.01\right)$ over the study period (2003-2015), with an average annual increase of $11.4 \%$. Along with the general increase in forest loss, there were several fluctuations in forest loss, which were the greatest in $2008\left(7734.8 \mathrm{~km}^{2}\right)$ and the lowest in 2003 $\left(2805.0 \mathrm{~km}^{2}\right)$ (Fig. 2).

Figure 3 displays the spatial distribution of trends (slope values from regression analysis) in forest loss during the study period (2003-2015) for each $0.5^{\circ} \times 0.5^{\circ}$ grid cells. In general, $25.7 \%$ of the grid cells showed an upward trend (slope value $>0$ ) in forest loss, among which $32.9 \%$ was

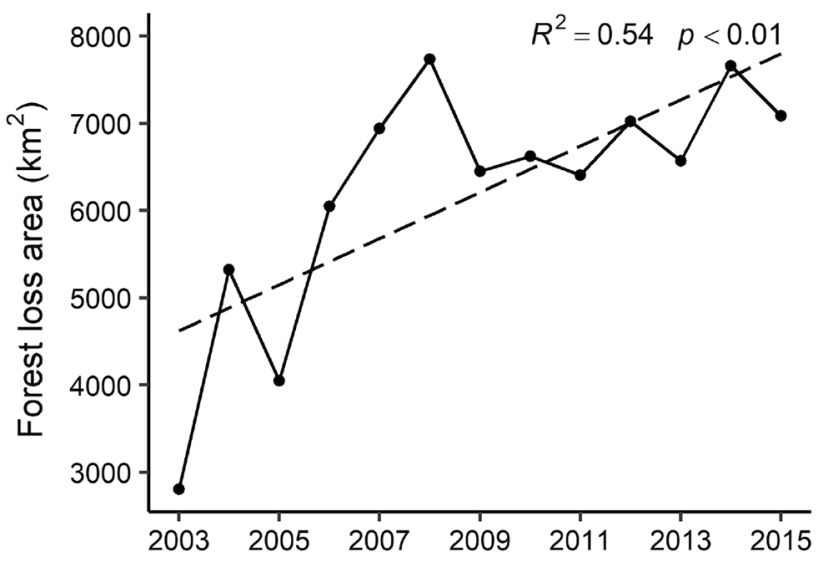

statistically significant $(p<0.05)$. Average regression slope values for all grid cells was $0.1 \mathrm{~km}^{2}$, with the largest rate of increase in annual forest loss having a slope of $4.5 \mathrm{~km}^{2}$, and the largest rate of decrease a slope of $9.5 \mathrm{~km}^{2}$ (Fig. 3).

Forest loss in forest zone IV increased at the highest rate (slope value) of $315.0 \mathrm{~km}^{2} \mathrm{a}^{-1}\left(R^{2}=0.69, p<0.01\right)$, followed by forest zone $\mathrm{V}$, which had an increasing rate of $38.8 \mathrm{~km}^{2} \mathrm{a}^{-1}\left(R^{2}=0.66, p<0.01\right)$. Other forest zones had a decreasing trend. Specifically, forest zone I had the greatest decreasing rate of $70.8 \mathrm{~km}^{2} \mathrm{a}^{-1}\left(R^{2}=0.75, p<0.01\right)$, followed by forest zone II $\left(-14.4 \mathrm{~km}^{2} \mathrm{a}^{-1} ; R^{2}=0.45\right.$, $p<0.05)$ and VI $\left(-3.5 \mathrm{~km}^{2} \mathrm{a}^{-1} ; R^{2}=0.35, p<0.05\right)$. Forest zone III had the weakest decreasing trend in forest loss $\left(-0.3 \mathrm{~km}^{2} \mathrm{a}^{-1} ; R^{2}=0.002, p>0.05\right)$ (Fig. 4).

\section{Spatiotemporal changes in burned area}

The results during 2003-2015 showed that an average of $1531.5 \mathrm{~km}^{2}$ of forests was burned. There was a general decrease over the study period, but the overall change in the burned area was nonsignificant $\left(R^{2}=0.22, p=0.10\right)$, although large fluctuations were observed. Specifically, the area burned was the greatest in $2008\left(3637.1 \mathrm{~km}^{2}\right)$ and lowest in $2015\left(865.2 \mathrm{~km}^{2}\right)$ (Fig. 5). On average, the burned area based on the MODIS-derived Global Fire Atlas data set was close to the area of affected forests $\left(1027.4 \mathrm{~km}^{2}\right)$ recorded in the government's fire statistics data set during 2003-2015.

By forest zone, the largest area of forest burned was in forest zone IV, where more than $589.2 \mathrm{~km}^{2}$ of forests burned annually (Fig. 6). Forest zone III had the smallest burned area $\left(8.8 \mathrm{~km}^{2} \mathrm{a}^{-1}\right)($ Table 1$)$.

\section{Correlation between forest loss and burned area}

The correlation coefficients relating forest loss to burned area are shown in Fig. 6 . We found that $13.8 \%$ of the grid cells $(n=567)$ had a positive correlation between forest loss and burned area $(r \geq 0.004)$, although only $1.0 \%$ cells $(n=41)$ were significantly positive $(r \geq 0.55, p<0.05)$. Only $0.3 \%$ of the gridded cells $(n=11)$ experienced a significant negative correlation $(r \leq-0.55, p<0.05)$ (Fig. 7).

We summarized the percentage of grid cells at different correlation levels within each forest zone (Table 2). This result showed that $16.9 \%$ of grid cells within forest zone I had a positive correlation between burned area and forest loss, followed by forest zone IV (7.8\%), zone V (5.9\%), zone II (3.7\%), zone III (2.7\%), and zone VI (0.9\%).
Fig. 2 Inter-annual variation in forest loss during 2003-2015. The dashed line indicates the linear fit of the regression equation 
Fig. 3 a Spatial distribution patterns of forest loss trends (linear regression slope) as a function of years between 2003 and 2015 across China; b significance of forest loss trends. The white areas indicate no loss found or land without forests. Zones: I, cold temperate deciduous coniferous forest zone; II, temperate deciduous mixed broadleaf and coniferous forest zone; III, warm temperate deciduous broadleaf-mixed forest zone; IV, subtropical evergreen broadleaf forest zone; $\mathrm{V}$, tropical rainforest zone; VI, vegetation zones in China that are not typically dominated by forests
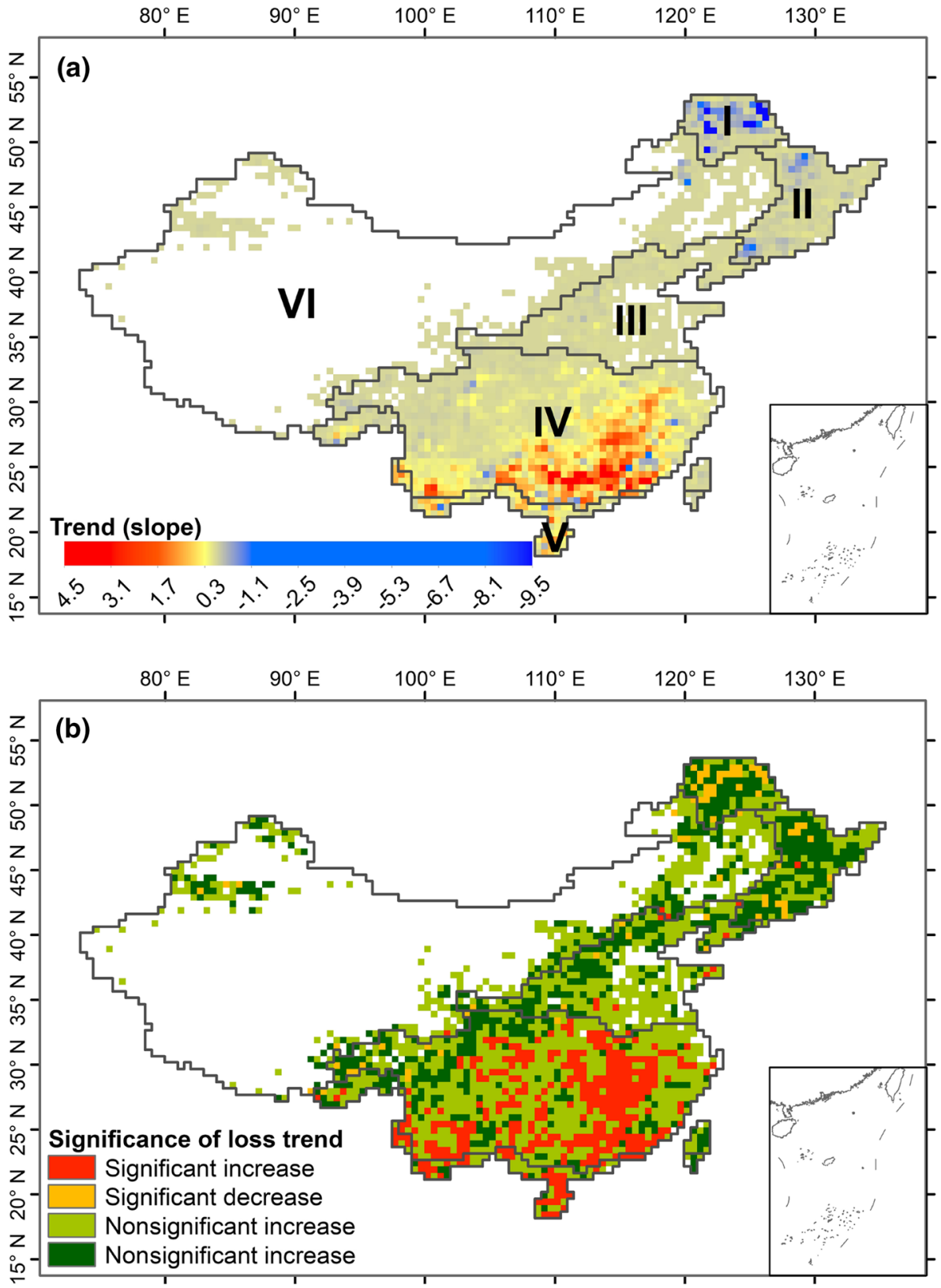

\section{Discussion}

Forest change comprises gains and losses, and the difference between the two determines the net change in a country's forest area in a given period. Our results showed that from 2003 to 2015, China's annual forest loss was $6209.2 \mathrm{~km}^{2}$, with an average annual increase in loss of $11.4 \%$. The forest loss data set in this study only recorded the complete removal of tree cover canopy as a result of human activities, including forestry practices such as timber harvesting or deforestation (the conversion of natural forest to other land uses), and natural causes such as fire or storm damage (Hansen et al. 2013). The forest loss data set in this study excluded forest gain due to afforestation in China. Therefore, it is worth noting that our results do not represent the net loss of forests in China. China has undertaken reforestation initiatives that have increased its forest cover dramatically in the last decades. From 2000 to 2010, for example, China's forest area increased by $327,808 \mathrm{~km}^{2}$, according to the National Forestry Inventory data set (Wang et al. 2015).

Our results showed that both forest loss and area burned were the highest in 2008, which was most obvious in forest 

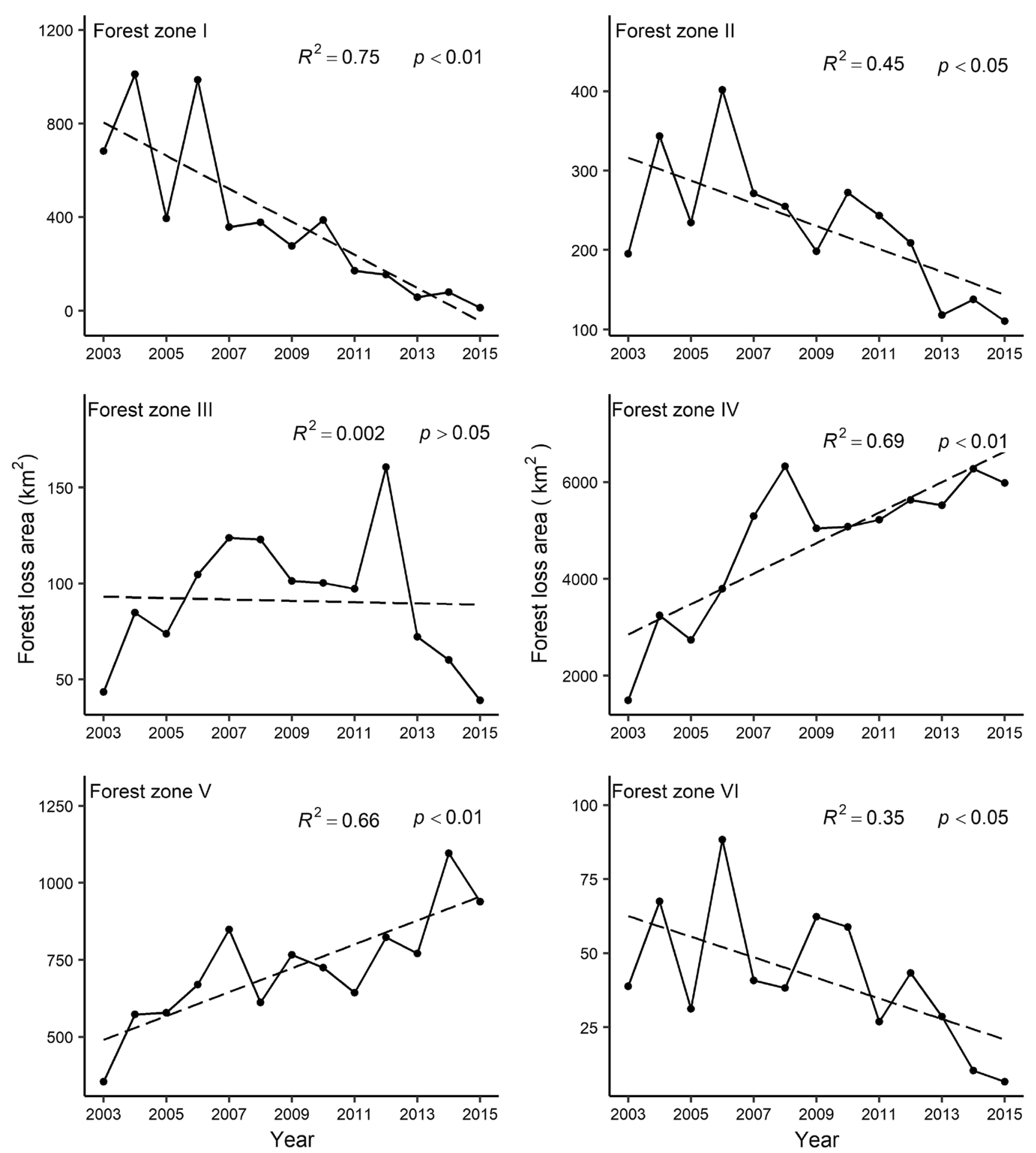

Fig. 4 Inter-annual variation in forest loss in China by forest zones during 2003-2015. The dashed line is the linear regression line for 2003-2015. Zones: I, cold temperate deciduous coniferous forest zone; II, temperate deciduous mixed broadleaf and coniferous forest

zone; III, warm temperate deciduous broadleaf-mixed forest zone; $\mathrm{IV}$, subtropical evergreen broadleaf forest zone; $\mathrm{V}$, tropical rainforest zone; VI, vegetation zones in China that are not typically dominated by forests 


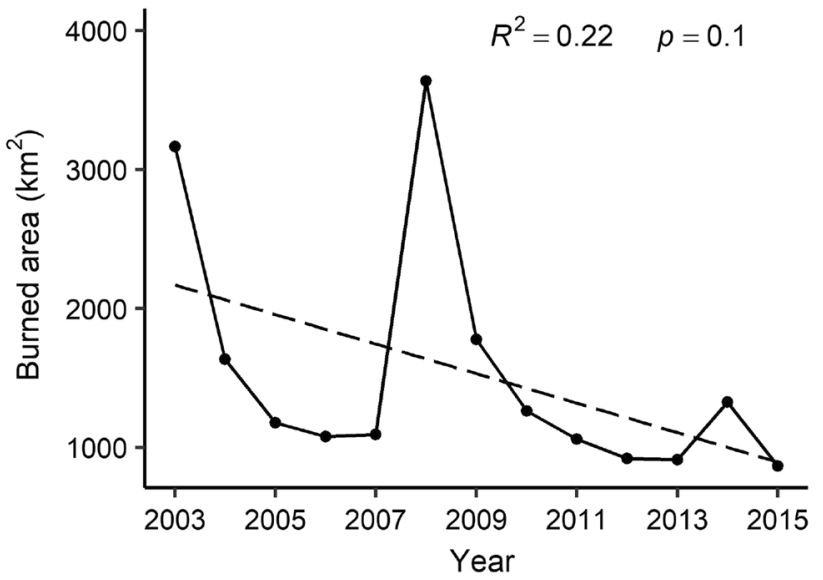

Fig. 5 Inter-annual variation in burned area over the 2003-2015 period. The dashed line is the linear regression line during 20032015 zone IV (subtropical evergreen broadleaf forest zone). We assume that the causes of forest loss in forest zone IV, located in southern China, partially explain the country-level trend in forest loss. During spring 2008, this region suffered its worst snow disaster in the last 50 years (Yang et al. 2008), which generated a large amount of forest fuel accumulation in the region, which then fueled the largest area of forest fires during the study period (Wang et al. 2008) and the largest forest loss in China in 2008.

Our results showed that the correlation between forest loss and burned area varied by forest zone (e.g., fire and forest conditions), in agreement with other studies (Potapov et al. 2008; Broich et al. 2011; Fanin and van der Werf 2015). For example, forest loss greatly varied spatially and temporally across Sumatra and Kalimantan Provinces, Indonesia, during 2000-2008 (Broich et al. 2011). Fires in China mainly occur in forest zones I (cold temperate deciduous coniferous forest zone) and IV (subtropical evergreen broadleaf forest zone). In this study, although forest loss in forest zone I was lower than that in zone IV, the correlation
Fig. 6 Spatial distribution of forest fire patches by forest zones in China over the 2003-2015 period. Zones: I, cold temperate deciduous coniferous forest zone; II, temperate deciduous mixed broadleaf and coniferous forest zone; III, warm temperate deciduous broadleaf-mixed forest zone; IV, subtropical evergreen broadleaf forest zone; V, tropical rainforest zone; VI, vegetation zones in China that are not typically dominated by forests

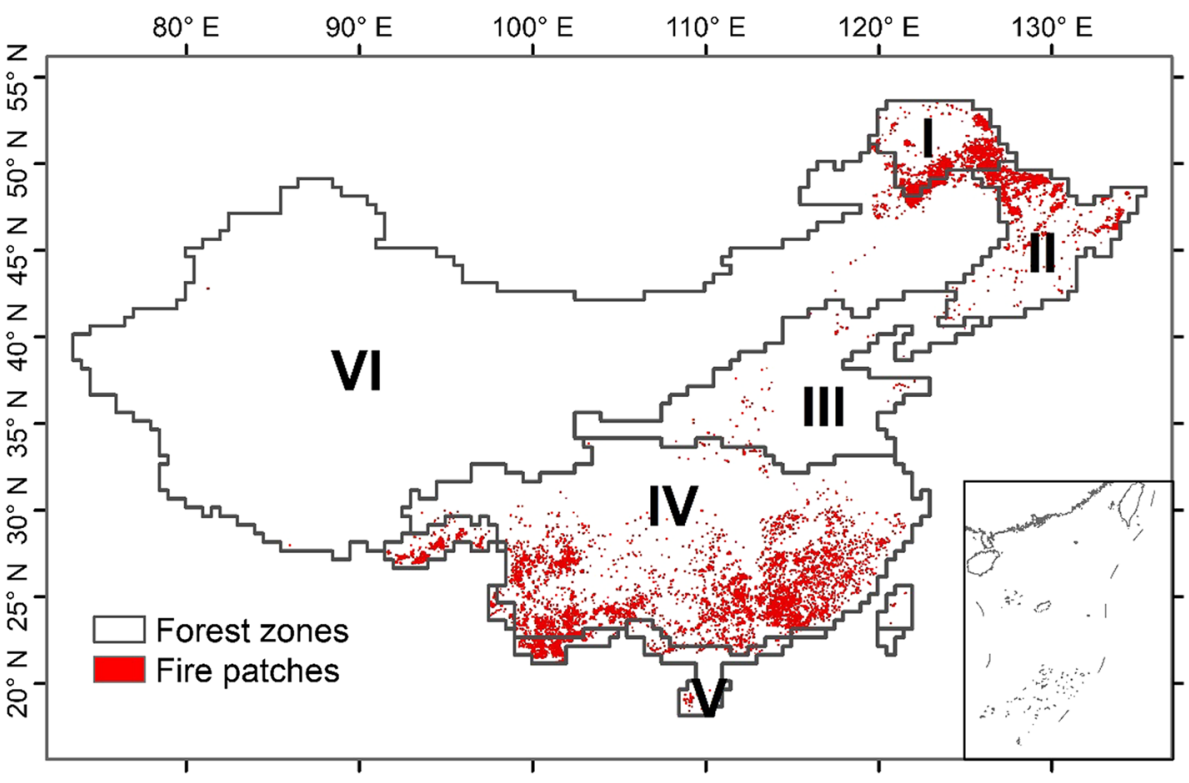

Table 1 Changes in burned area $\left(\mathrm{km}^{2}\right)$ in six forest zones in China between 2003 and 2015

\begin{tabular}{|c|c|c|c|c|c|c|c|c|c|c|c|c|c|}
\hline Forest zones & 2003 & 2004 & 2005 & 2006 & 2007 & 2008 & 2009 & 2010 & 2011 & 2012 & 2013 & 2014 & 2015 \\
\hline I & 1005.0 & 249.3 & 103.3 & 262.3 & 123.5 & 741.6 & 82.9 & 23.1 & 300.2 & 75.1 & 73.2 & 222.8 & 195.4 \\
\hline II & 1192.1 & 326.3 & 374.9 & 258.8 & 130.6 & 617.2 & 442.0 & 20.2 & 386.2 & 130.6 & 221.8 & 204.3 & 348.3 \\
\hline III & 0.4 & 0.8 & 1.2 & 2.4 & 34.2 & 1.0 & 4.7 & 2.3 & 9.3 & 3.1 & 20.6 & 28.9 & 5.2 \\
\hline IV & 509.7 & 676.3 & 524.3 & 305.7 & 496.1 & 1446.1 & 783.4 & 1013.5 & 207.9 & 445.3 & 420.7 & 642.8 & 187.7 \\
\hline V & 224.3 & 362.6 & 137.5 & 165.5 & 298.2 & 68.7 & 402.8 & 175.7 & 104.5 & 250.5 & 172.6 & 178.2 & 108.5 \\
\hline VI & 234.4 & 19.7 & 37.8 & 83.8 & 8.9 & 762.5 & 62.1 & 26.9 & 52.8 & 16.9 & 2.2 & 47.6 & 20.1 \\
\hline
\end{tabular}

Zones: I, cold temperate deciduous coniferous forest zone; II, temperate deciduous mixed broadleaf and coniferous forest zone; III, warm temperate deciduous broadleaf-mixed forest zone; IV, subtropical evergreen broadleaf forest zone; V, tropical rainforest zone; VI, vegetation zones in China that are not typically dominated by forests 
Fig. 7 a Spatial patterns of correlation between forest loss and burned area across China between 2003 and 2015; b significance of correlation coefficients. White areas denote no loss observed or uncovered by forests. Zones: I, cold temperate deciduous coniferous forest zone; II, temperate deciduous mixed broadleaf and coniferous forest zone; III, warm temperate deciduous broadleaf-mixed forest zone; IV, subtropical evergreen broadleaf forest zone; $\mathrm{V}$, tropical rainforest zone; VI, vegetation zones in China that are not typically dominated by forests
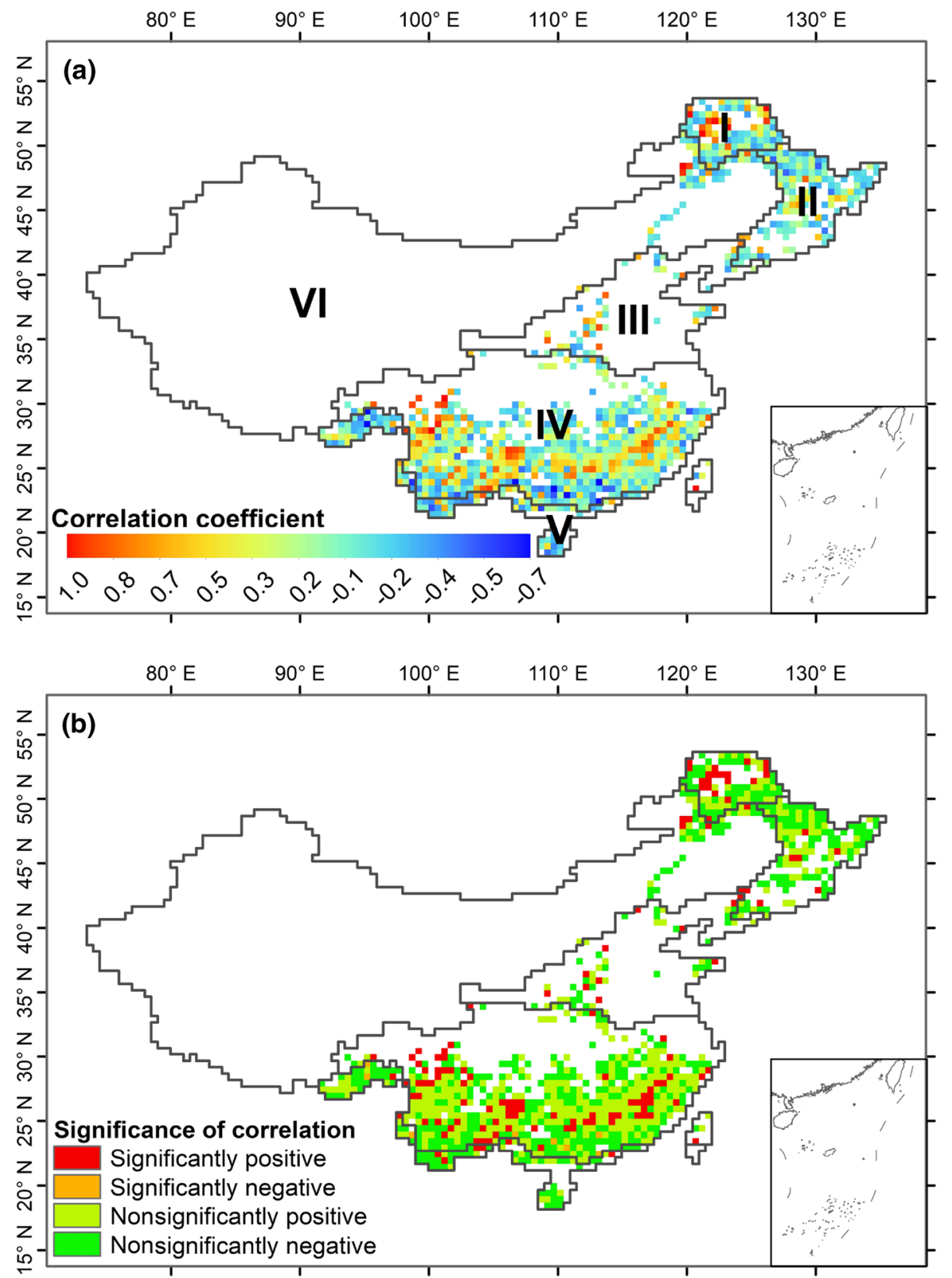

between forest loss and burned area was higher in zone I. Forest zone I is located in the deciduous coniferous forest region (boreal forests) of China, where the frequency of forest fires is low but the burned area is usually large (high tree mortality), thus accounting for the majority of the national area affected by fire (Chang et al. 2015). A strong relationship between forest loss and fire in boreal forests was found in other studies. For example, about $58.9 \%$ of total forest loss from 2000 to 2005 was attributable to wildfires within the boreal biome (Potapov et al. 2008). In contrast, fires covering less area with lower intensity (lower tree mortality) are more common in the hot, humid subtropical evergreen broadleaved forests (zone IV) in southern China. Therefore, the correlation between forest loss and burned area in the forest zone IV was lower. In most of the grid cells in forests zones II, III, and V, the correlation between forest loss and burned area was not strong. This result may be related to the vegetation cover and human activities in these forest zones. For example, many people reside in low-relief plains in forest zone II (temperate deciduous mixed broadleaf-conifer forests) and strongly affect regional fire regimes, especially by burning crop residues before planting (expansion 
Table 2 Percentage of grid cells at different correlation levels within each forest zone in China

\begin{tabular}{lllll}
\hline Forest zone & $\begin{array}{l}\text { Sig- } \\
\text { nificantly } \\
\text { positive }\end{array}$ & $\begin{array}{l}\text { Sig- } \\
\text { nificantly } \\
\text { negative }\end{array}$ & $\begin{array}{l}\text { Nonsig- } \\
\text { nificantly } \\
\text { positive }\end{array}$ & $\begin{array}{l}\text { Nonsig- } \\
\text { nificantly } \\
\text { negative }\end{array}$ \\
\hline I & 16.9 & 0 & 22 & 37.3 \\
II & 3.7 & 0 & 22.5 & 36.2 \\
III & 2.7 & 0 & 5 & 6.2 \\
IV & 7.8 & 0.5 & 26.4 & 21.2 \\
V & 5.9 & 2 & 19.7 & 43.4 \\
VI & 0.9 & 0 & 2.7 & 5.3 \\
\hline
\end{tabular}

Zones: I, cold temperate deciduous coniferous forest zone; II, temperate deciduous mixed broadleaf and coniferous forest zone; III, warm temperate deciduous broadleaf-mixed forest zone; IV, subtropical evergreen broadleaf forest zone; V, tropical rainforest zone; VI, vegetation zones in China that are not typically dominated by forests

of agricultural fire fronts into forests) (Zhang et al. 2015). Roads are well developed, and population density is high in the forest zone V (tropical rainforest zone). Fires in forest zones II and $\mathrm{V}$ are easier to discover and suppress once they occur; consequently, tree mortality is usually lower than in areas with low population density, such as in forest zone I. Forest zone III (warm temperate deciduous broadleaf-mixed forests) is generally characterized by low forest coverage and low forest fire frequency, which results in a weak correlation between forest loss and burned area.

One uncertainty is the MODIS burned-area data, which are useful for detecting relatively large fires. Therefore, not all fires (e.g., some small fires) were detected. The use of high-resolution observations may improve the accuracy of national-scale burned area in future studies (Reiche et al. 2018). In addition, most grid cells showed no strong correlation between forest loss and burned area. First, our study focused on analyzing patterns of forest loss in the fire burning year. There may exist a time-lag effect of fires, meaning forest loss likely occurs after fire burning over a longer period (e.g., years after fire burning). Second, studies suggest that other causes of forest loss should be considered (van Lierop et al. 2015), such as urban expansion (Zhou et al. 2017), timber harvesting (Wu et al. 2019), and ice storm damage (Yang et al. 2008). For example, urban expansion was suggested as a major factor causing forest loss in six mega regions of southern China (Zhou et al. 2017). Consequently, our next step would be to incorporate vegetation dynamics models to address feedback effects of forest to fire and other disturbances (e.g., urban expansion).

Our study showed that forest loss caused by fires in boreal forests (forest zone I) accounted for the largest proportion of forest loss. Therefore, timely monitoring of forest loss in this region is needed. In addition, quantifying forest loss change is an important step in documenting carbon exchange estimates; for example, quantifying and comparing the amount of carbon consumed following a fire across China and by forest zones (Potapov et al. 2009; Brown and Johnstone 2011). The results of forest loss and burned area correlations can provide a basis for a national-scale fire impact prediction model (Dennis and Colfer 2006).

\section{Conclusions}

Our main findings from our analysis of forest loss and its relation to forest biomass burned in China between 2003 and 2015 are that (1) China's forest loss has increased significantly $\left(264.8 \mathrm{~km}^{2} \mathrm{a}^{-1}\right)$ with an average annual increase of $11.4 \%$ over the past 13 years; (2) forest loss trends varied greatly in the six forest zones; forest loss rates have significantly declined in forest zones I, II, and VI, but forest loss in forest zones IV and V has significantly increased; and (3) the correlation between forest loss and burned area was the strongest in forest zone I and weakest in forest zone VI. Results from this study will help guide the allocation of resources for forest monitoring and enforcement efforts to reduce fire-induced forest loss across the country.

Acknowledgements We are grateful to Zhihua Liu for his constructive comments to improve the manuscript.

Open Access This article is distributed under the terms of the Creative Commons Attribution 4.0 International License (http://creativeco mmons.org/licenses/by/4.0/), which permits unrestricted use, distribution, and reproduction in any medium, provided you give appropriate credit to the original author(s) and the source, provide a link to the Creative Commons license, and indicate if changes were made.

\section{References}

Abatzoglou JT, Williams AP (2016) Impact of anthropogenic climate change on wildfire across western US forests. Proc Natl Acad Sci USA 113(42):11770-11775

Adams MA, Shen ZH (2015) Introduction to the characteristics, impacts and management of forest fire in China. For Ecol Manag $356: 1$

Andela N, Morton DC, Giglio L, Paugam R, Chen Y, Hantson S, van der Werf GR, Randerson JT (2019) The Global Fire Atlas of individual fire size, duration, speed and direction. Earth Syst Sci Data 11(2):529-552

Betts MG, Wolf C, Ripple WJ, Phalan B, Millers KA, Duarte A, Butchart SHM, Levi T (2017) Global forest loss 
disproportionately erodes biodiversity in intact landscapes. Nature 547(7664):441-444

Bonan GB (2008) Forests and climate change: forcings, feedbacks, and the climate benefits of forests. Science 320(5882):1444-1449

Brando PM, Balch JK, Nepstad DC, Morton DC, Putz FE, Coe MT, Silverio D, Macedo MN, Davidson EA, Nobrega CC, Alencar A, Soares BS (2014) Abrupt increases in Amazonian tree mortality due to drought-fire interactions. Proc Natl Acad Sci USA 111(17):6347-6352

Broich M, Hansen M, Stolle F, Potapov P, Margono BA, Adusei B (2011) Remotely sensed forest cover loss shows high spatial and temporal variation across Sumatera and Kalimantan, Indonesia 2000-2008. Environ Res Lett 6(1):014010

Brown CD, Johnstone JF (2011) How does increased fire frequency affect carbon loss from fire? A case study in the northern boreal forest. Int J Wildland Fire 20(7):829-837

Cahoon DR, Stocks BJ, Levine JS, Cofer WR, Pierson JM (1994) Satellite analysis of the severe 1987 forest-fires in Northern China and Southeastern Siberia. J Geophys Res Atmos 99(D9):18627-18638

Chang Y, Zhu ZL, Bu RC, Li YH, Hu YM (2015) Environmental controls on the characteristics of mean number of forest fires and mean forest area burned (1987-2007) in China. For Ecol Manag 356:13-21

Chen DM, Pereira JMC, Masiero A, Pirotti F (2017) Mapping fire regimes in China using MODIS active fire and burned area data. Appl Geogr 85:14-26

Chiriaco MV, Perugini L, Cimini D, D’Amato E, Valentini R, Bovio G, Corona P, Barbati A (2013) Comparison of approaches for reporting forest fire-related biomass loss and greenhouse gas emissions in southern Europe. Int J Wildland Fire 22(6):730-738

Curtis PG, Slay CM, Harris NL, Tyukavina A, Hansen MC (2018) Classifying drivers of global forest loss. Science 361(6407):1108-1111

Da Ponte E, Roch M, Leinenkugel P, Dech S, Kuenzer C (2017) Paraguay's Atlantic Forest cover loss Satellite-based change detection and fragmentation analysis between 2003 and 2013. Appl Geogr 79:37-49

Dennis RA, Colfer CP (2006) Impacts of land use and fire on the loss and degradation of lowland forest in 1983-2000 in East Kutai District, East Kalimantan, Indonesia. Singap J Trop Geogr 27(1):30-48

Fanin T, van der Werf GR (2015) Relationships between burned area, forest cover loss, and land cover change in the Brazilian Amazon based on satellite data. Biogeosciences 12(20):6033-6043

Foley JA, Asner GP, Costa MH, Coe MT, DeFries R, Gibbs HK, Howard EA, Olson S, Patz J, Ramankutty N, Snyder P (2007) Amazonia revealed: forest degradation and loss of ecosystem goods and services in the Amazon Basin. Front Ecol Environ 5(1):25-32

Fornacca D, Ren GP, Xiao W (2017) Performance of three MODIS fire products (MCD45A1, MCD64A1, MCD14ML), and ESA Fire CCI in a mountainous area of Northwest Yunnan, China, characterized by frequent small fires. Remote Sens Basel 9(11):1131

Giglio L, Randerson JT, van der Werf GR, Kasibhatla PS, Collatz GJ, Morton DC, DeFries RS (2010) Assessing variability and longterm trends in burned area by merging multiple satellite fire products. Biogeosciences 7(3):1171-1186

Guo FT, Su ZW, Wang GY, Sun L, Tigabu M, Yang XJ, Hu HQ (2017) Understanding fire drivers and relative impacts in different Chinese forest ecosystems. Sci Total Environ 605:411-425

Hansen MC, DeFries RS, Townshend JRG, Carroll M, Dimiceli C, Sohlberg RA (2003) Global percent tree cover at a spatial resolution of 500 meters: first results of the MODIS vegetation continuous fields algorithm. Earth Interact 7:1-15
Hansen MC, Egorov A, Roy DP, Potapov P, Ju JC, Turubanova S, Kommareddy I, Loveland TR (2011) Continuous fields of land cover for the conterminous United States using Landsat data: first results from the Web-Enabled Landsat Data (WELD) project. Remote Sens Lett 2:279-288

Hansen MC, Potapov PV, Moore R, Hancher M, Turubanova SA, Tyukavina A, Thau D, Stehman SV, Goetz SJ, Loveland TR, Kommareddy A, Egorov A, Chini L, Justice CO, Townshend JRG (2013) High-resolution global maps of 21st-century forest cover change. Science 342(6160):850-853

Harris NL, Goldman E, Gabris C, Nordling J, Minnemeyer S, Ansari S, Lippmann M, Bennett L, Raad M, Hansen M, Potapov P (2017) Using spatial statistics to identify emerging hot spots of forest loss. Environ Res Lett 12(2):024012

Heino M, Kummu M, Makkonen M, Mulligan M, Verburg PH, Jalava M, Rasanen TA (2015) Forest loss in protected areas and intact forest landscapes: a global analysis. PLoS ONE 10(10):e0138918

Jia MM, Wang ZM, Zhang YZ, Ren CY, Song KS (2015) Landsatbased estimation of mangrove forest loss and restoration in Guangxi Province, China, influenced by human and natural factors. IEEE J Stars 8(1):311-323

Keenan RJ, Reams GA, Achard F, de Freitas JV, Grainger A, Lindquist E (2015) Dynamics of global forest area: results from the FAO global forest resources assessment 2015. For Ecol Manag 352:9-20

Lehtomaki J, Tuominen S, Toivonen T, Leinonen A (2015) What data to use for forest conservation planning? A comparison of coarse open and detailed proprietary forest inventory data in Finland. PLoS ONE 10(8):e0135926

Li JF, Song Y, Huang X, Li MM (2015) Comparison of forest burned areas in mainland China derived from MCD45A1 and data recorded in yearbooks from 2001 to 2011. Int J Wildland Fire 24(1):103-113

Liu YQ, Stanturf J, Goodrick S (2010) Trends in global wildfire potential in a changing climate. For Ecol Manag 259:685-697

Molin PG, Gergel SE, Soares BS, Ferraz SFB (2017) Spatial determinants of atlantic forest loss and recovery in Brazil. Landsc Ecol 32(4):857-870

Perry GLW, Wilmshurst JM, McGlone MS, Napier A (2012) Reconstructing spatial vulnerability to forest loss by fire in pre-historic New Zealand. Glob Ecol Biogeogr 21(10):1029-1041

Piao SL, Fang JY, Ji W, Guo QH, Ke JH, Tao S (2004) Variation in a satellite-based vegetation index in relation to climate in China. J Veg Sci 15(2):219-226

Potapov P, Hansen MC, Stehman SV, Loveland TR, Pittman K (2008) Combining MODIS and Landsat imagery to estimate and map boreal forest cover loss. Remote Sens Environ 112(9):3708-3719

Potapov P, Hansen MC, Stehman SV, Pittman K, Turubanova S (2009) Gross forest cover loss in temperate forests: biome-wide monitoring results using MODIS and Landsat data. J Appl Remote Sens $3(1): 1-23$

Reiche J, Verhoeven R, Verbesselt J, Hamunyela E, Wielaard N, Herold M (2018) Characterizing tropical forest cover loss using dense sentinel-1 data and active fire alerts. Remote Sens Basel 10(5):rs 10050777

Reilly MJ, Elia M, Spies TA, Gregory MJ, Sanesi G, Lafortezza R (2018) Cumulative effects of wildfires on forest dynamics in the eastern Cascade Mountains, USA. Ecol Appl 28(2):291-308

Sannier C, McRoberts RE, Fichet LV (2016) Suitability of global forest change data to report forest cover estimates at national level in Gabon. Remote Sens Environ 173:326-338 
Stephens SL, Agee JK, Fule PZ, North MP, Romme WH, Swetnam TW, Turner MG (2013) Managing forests and fire in changing climates. Science 342(6154):41-42

R Core Team (2018) R: a language and environment for statistical computing. R foundation for statistical computing, Vienna, Austria. https://www.R-project.org

Tepley AJ, Thompson JR, Epstein HE, Anderson-Teixeira KJ (2017) Vulnerability to forest loss through altered postfire recovery dynamics in a warming climate in the Klamath Mountains. Glob Change Biol 23(10):4117-4132

Tian XR, Zhao FJ, Shu LF, Wang MY (2013) Distribution characteristics and the influence factors of forest fires in China. For Ecol Manag 310:460-467

Trumbore S, Brando P, Hartmann H (2015) Forest health and global change. Science 349(6250):814-818

van der Werf GR, Morton DC, DeFries RS, Olivier JGJ, Kasibhatla PS, Jackson RB, Collatz GJ, Randerson JT (2009) $\mathrm{CO}_{2}$ emissions from forest loss. Nat Geosci 2(11):737-738

van Lierop P, Lindquist E, Sathyapala S, Franceschini G (2015) Global forest area disturbance from fire, insect pests, diseases and severe weather events. For Ecol Manag 352:78-88

Wang QH, Shu LF, Dai XA, Wang MY, Tian XR (2008) Effects of snow and ice disasters on forest fuel and fire behaviors in the Southern China. Sci Silva Sin 44(11):171-176 (in Chinese with English abstract)

Wang H, Lü Z, Gu L, Wen C (2015) Observations of China's forest change (2000-2013) based on global forest watch dataset. Biodivers Sci 23(5):575-582 (in Chinese with English abstract)
Wotton BM, Nock CA, Flannigan MD (2010) Forest fire occurrence and climate change in Canada. Int J Wildland Fire 19(3):253-271

Wu Z, Dai EF, Wu ZF, Lin MZ (2019) Future forest dynamics under climate change, land use change, and harvest in subtropical forests in Southern China. Landsc Ecol 34(4):843-863

Xiao DN, Tao DL, Xu ZB (1988) Impacts of an extra-ordinarily disastrous fire on forest resources and environment. Chin J Ecol 7(Suppl.):5-9

Yang FW, Lu SW, Wang B (2008) Value estimation of service function of forest ecosystem damaged by frozen rain and snow in the South China. Sci Silva Sin 44(11):101-110 (in Chinese with English abstract)

Zhai D, Xu J, Dai Z, Schmidt-Vogt D (2017) Lost in transition: forest transition and natural forest loss in tropical China. Plant Divers 39(3):149-153

Zhang ZQ, Zhong JJ, Lv XG, Tong SZ, Wang GP (2015) Climate, vegetation, and human influences on late-Holocene fire regimes in the Sanjiang plain, northeastern China. Palaeogeogr Palaeocl 438:1-8

Zhou WQ, Zhang S, Yu WJ, Wang J, Wang WM (2017) Effects of urban expansion on forest loss and fragmentation in six megaregions, China. Remote Sens Basel 9(10):rs9100991

Publisher's Note Springer Nature remains neutral with regard to jurisdictional claims in published maps and institutional affiliations. 